\title{
Model Jaringan Syaraf Tiruan Dalam Memprediksi Ketersediaan Cabai Berdasarkan Provinsi
}

\author{
Devi Monika \\ Program Studi Manajemen Informatika \\ AMIK Tunas Bangsa \\ monicadevi501@gmail.com \\ Sri Wardani \\ Program Studi Manajemen Informatika \\ AMIK Tunas Bangsa \\ sriwardani90804@gmail.com
}

\author{
Abdullah Ahmad \\ Program Studi Manajemen Informatika \\ AMIK Tunas Bangsa \\ ahmadabdullah400@yahoo.com \\ Solikhun \\ Program Studi Manajemen Informatika \\ AMIK Tunas Bangsa \\ solikhun@amiktunasbangsa.ac.id
}

\begin{abstract}
Abstrak - Tanaman cabai adalah bumbu masakan yang saling melengkapi. Harga cabai selalu berfluktuasi. Tercatat dari 2012 hingga 2017, produksi tanaman cabai besar (ton) di setiap provinsi berfluktuasi. Pemerintah membutuhkan prediksi ketersediaan tanaman cabai berdasarkan provinsi di Indonesia untuk meningkatkan ketahanan pangan, terutama produksi cabai. Penelitian ini memberikan kontribusi kepada pemerintah untuk dapat memprediksi ketersediaan tanaman cabai berdasarkan provinsi di Indonesia di masa depan. Data yang digunakan adalah data dari Badan Pusat Statistik melalui situs web www.bps.go.id. Data tersebut adalah data tentang ketersediaan tanaman cabai menurut provinsi di Indonesia dari 2012 hingga 2017. Algoritma yang digunakan dalam penelitian ini adalah Jaringan Syaraf Tiruan dengan metode Backpropogation. Variabel input yang digunakan adalah data 2012 (X1), data 2013 (X2), data 2014 (X3), dan data 2015 (X4) dengan 4 pelatihan arsitektur dan model pengujian, 4-2-1, 4-3-1, 44-1, dan 4-5-1. Data target diambil dari data 2016 (T). Output yang dihasilkan adalah pola terbaik dari arsitektur JST. Model arsitektur terbaik adalah 4-5-1 dengan zaman 670, MSE 0,010651, dan tingkat akurasi 99,97.
\end{abstract}

Kata Kunci: Backpropogation, JST, Ketersediaan Tanaman Cabai, Prediksi

\section{PENDAHULUAN}

Komoditas cabai bukan termasuk pangan pokok bagi masyarakat Indonesia, akan tetapi perannya sebagai bumbu pelengkap masakan, ditunjang harganya yang selalu fluktuatif, tak jarang cabai menyumbang inflasi bagi perekonomian nasional. Komoditas cabai di Indonesia terdiri dari berbagai varian. Diantaranya cabai besar yang terdiri dari cabai merah besar dan cabai merah keriting, serta cabai rawit yang terdiri dari cabai rawit hijau dan cabai rawit merah. Diantara varian tersebut, cabai merah keriting adalah cabai yang paling sering dikonsumsi oleh masyarakat. Dari sisi harga, cabai rawit merah adalah komoditas yang paling fluktuatif, tak jarang harganya melebihi Rp. 100.000/kg terutama di musim paceklik.

Profil komoditas cabai ini bertujuan untuk memberikan ulasan mengenai keragaman tata niaga komoditas cabai nasional diantaranya perkembangan ketersediaan komoditas cabai nasional, perkembangan harga komoditas cabai nasional, perkembangan distribusi komoditas cabai nasional, perkembangan konsumsi komoditas cabai nasional, perkembangan ekspor-impor cabai nasional serta analisis kebijakan dan regulasi cabai nasional. Analisis ketersediaan komoditas cabai ini akan diulas dan dibahas dalam penelitian ini. Tujuannya sebagai salah satu upaya untuk mendapatkan gambaran kondisi dan model peramalan neraca kebutuhan dan ketersediaan pasokan yang akurat sehingga hasil analisis akan dapat digunakan dalam menetapkan kebijakan yang tepat. Permintaan komoditas sayuran umumnya sangat sensitif terhadap perubahan kesegaran produk. Sementara itu komoditas sayuran umumnya relatif cepat busuk sehingga petani dan pedagang tidak mampu menahan penjualannya terlalu lama dalam rangka mengatur volume pasokan yang sesuai dengan kebutuhan pasar, karena hal itu dapat berdampak pada penurunan harga jual yang disebabkan oleh penurunan kesegaran produk. Konsekuensinya adalah pengaturan volume pasokan yang disesuaikan dengan kebutuhan konsumen tidak mudah dilakukan karena setelah dipanen petani cenderung segera menjual hasil panennya agar sayuran yang dipasarkan masih dalam keadaan segar [1].

Tercatat dari tahun 2012 hingga tahun 2017, produksi tanaman sayuran cabai besar (ton) pada setiap provinsi di Indonesia berbeda-beda dan setiap provinsinya bersifat fluktuatif. Bahkan ada juga provinsi yang tidak memiliki produksi cabai di wilayahnya yaitu provinsi DKI Jakarta. 
Produksi cabai besar yang tidak stabil tersebut terkadang menjadi permasalahan tersendiri, seperti tidak mencukupinya ketersediaan cabai besar di dalam negeri sehingga memaksa pemerintah untuk impor cabai besar dari luar negeri. Tentunya hal tersebut menjadi ironis, mengingat negeri yang subur dan kaya akan Sumber Daya Alam ini belum mampu mengolah kekayaannya demi kecukupan bahan pangannya sendiri. Selain itu produksi cabai besar yang tidak seimbang dengan laju pertumbuhan penduduk yang kian meningkat dapat menjadi salah satu pemicu tidak cukupnya produksi cabai besar dalam negeri.

Melihat permasalahan yang cukup kompleks tersebut, tentunya dibutuhkan suatu metode yang dapat lebih efektif dalam memprediksi ketersediaan produksi cabai berdasarkan provinsi dalam pemenuhan kebutuhan bahan masak pangan di Indonesia. Adapun metode yang akan digunakan dalam memprediksi ketersediaan komoditas cabai berdasarkan provinsi di Indonesia adalah metode Jaringan Syaraf Tiruan (JST). Peneliti dalam penerapannya menggunakan sebuah teknik peramalan yang dapat digunakan untuk melakukan prediksi yaitu backpropagation. Dengan menggunakan teknik ini dimaksudkan untuk membuat sebuah sistem yang dapat memprediksi ketersediaan produksi cabai berdasarkan provinsi di Indonesia. Diharapkan melalui sistem ini dapat membantu pemerintah dalam memprediksi ketersediaan produksi cabai berdasarkan provinsi di Indonesia dan mampu meningkatkan ketahanan pangan di Indonesia khususnya produksi cabai.

\section{METODOLOGI PENELITIAN}

\section{A. Kecerdasan Buatan (Artificial Intellegence)}

Kecerdasan buatan atau disebut juga Artificial Intelligence (AI) merupakan salah satu bagian dari ilmu komputer yang mempelajari bagaimana membuat mesin (komputer) dapat melakukan pekerjaan seperti dan sebaik yang dilakukan oleh manusia, bahkan bisa lebih baik daripada yang dilakukan manusia [2].

\section{B. Jaringan Syaraf Tiruan}

Jaringan syaraf tiruan (JST) adalah paradigma pemrosesan suatu informasi yang terinspirasi oleh sistem sel syaraf biologi. Jaringan ini biasanya diimplementasikan dengan menggunakan komponen elektronik atau disimulasikan pada aplikasi komputer [3].

\section{Arsitektur Jaringan Syaraf Tiruan}

Backpropagation memiliki beberapa unit yang ada dalam satu atau lebih lapis tersembunyi. Pada Gambar 1 adalah arsitektur Backpropagation dengan $n$ buah masukan ( $x 1, x 2$, $x 3, \ldots \ldots . x n)$ ditambah sebuah bias, sebuah lapis tersembunyi yang terdiri dari $j$ unit ditambah sebuah bias, serta $k$ buah unit keluaran [4].

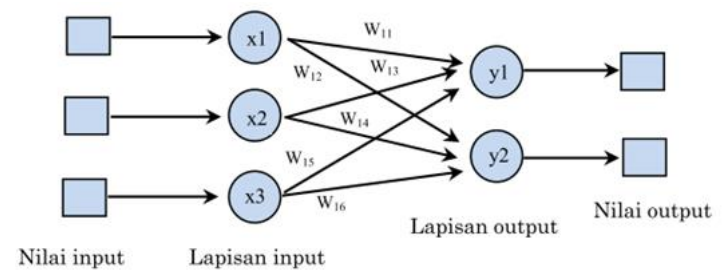

Gambar 1. Arsitektur Lapisan Tunggal.

Simbol-simbol yang digunakan ini tidaklah mutlak, bisa saja berganti dengan simbol-simbol yang lainnya asalkan fungsi logika yang dimaksudkannya tetap sama. Secara sederhana dapat dikatakan bahwa jika output memberikan hasil yang salah, maka penimbang (bobot) dikoreksi supaya error (galat) dapat diperkecil dan respon jaringan selanjutnya diharapkan akan lebih mendekati harga yang benar.

\section{Prediksi/Peramalan}

Prediksi/peramalan adalah proses untuk memperkirakan berapa kebutuhan dimasa yang akan datang yang meliputi kebutuhan dalam ukuran kuantitas, kualitas, waktu, dan lokasi yang dibutuhkan dalam rangka memenuhi permintaan barang ataupun jasa [5].

\section{E. Karakteristik Jaringan Syaraf Tiruan}

Jaringan Syaraf Tiruan memiliki beberapa karakteristik yang unik, diantaranya adalah:

1. Kemampuan untuk belajar.

2. Kemampuan untuk mengeneralisasi.

3. Kemampuan untuk memecahkan permasalahan yang tidak bisa atau kurang baik bila dimodelkan sebagai sistem linier, yang menjadi persyaratan pada beberapa metode peramalan lainnya, seperti model data deret waktu (time series model) [6].

F. Model Jaringan Syaraf Tiruan yang Digunakan

Model yang digunakan pada penelitian ini adalah model Backpropagation. Backpropagation adalah salah satu model JST yang mempunyai kemampuan mendapatkan keseimbangan antara kemampuan jaringan untuk mengenali pola yang digunakan selama pelatihan serta kemampuan jaringan untuk memberikan respon yang benar terhadap pola masukan yang serupa (tapi tidak sama) dengan pola yang dipakai selama pelatihan [7].

Terdapat 3 fase dalam pelatihan Backpropagation, yaitu fase maju (feed forward), fase mundur (back propagation), dan fase modifikasi bobot. Dalam fase feed forward, pola masukan dihitung maju dimulai dari lapisan input hingga lapisan output. Dalam fase back propagation, tiap-tiap unit output menerima target pola yang berhubungan dengan pola input untuk dihitung nilai kesalahan. Kesalahan tersebut akan dipropagasikan mundur. Sedangkan fase modifikasi bobot bertujuan untuk menurunkan kesalahan yang terjadi. Ketiga fase tersebut diulang secara terus menerus hingga kondisi penghentian dipenuhi [8].

Secara rinci algoritma pelatihan jaringan Backpropagation dapat diuraikan sebagai berikut [9]: 
- Langkah 0: Inisialisasi bobot-bobot, konstanta laju pelatihan $(\alpha)$, toleransi error atau nilai bobot (bila menggunakan nilai bobot sebagai kondisi berhenti) atau set maksimal epoch (jika menggunakan banyaknya epoch sebagai kondisi berhenti).

- Langkah 1: Selama kondisi berhenti belum dicapai, maka lakukan langkah ke-2 hingga langkah ke-9.

- Langkah 2: Untuk setiap pasangan pola pelatihan, lakukan langkah ke-3 sampai langkah ke-8.

- Langkah 3: \{Tahap I: Umpan maju (feedforwand) \}. Tiap unit masukan menerima sinyal dan meneruskannya ke unit tersembunyi di atasnya.

- Langkah 4: Masing-masing unit di lapisan tersembunyi (dari unit ke-1 hingga unit ke-p) dikalikan dengan bobotnya dan dijumlahkan serta ditambahkan dengan biasnya.

- Langkah 5: Masing-masing unit output (yk,k=1,2,3,...m) dikalikan dengan bobot dan dijumlahkan serta ditambahkan dengan biasnya.

- Langkah 6: \{Tahap II: Umpan mundur (backward propagation)\}. Masing-masing unit output (yk,k=1,2,3,..m) menerima pola target tk sesuai dengan pola masukan/input saat pelatihan dan kemudian informasi kesalahan/error lapisan output ( $\delta \mathrm{k})$ dihitung. $\delta \mathrm{k}$ dikirim ke lapisan di bawahnya dan digunakan untuk menghitung besarnya koreksi bobot dan bias $(\Delta \mathrm{Wjk}$ dan $\Delta$ Wok ) antara lapisan tersembunyi dengan lapisan output.

- Langkah 7: Pada setiap unit dilapisan tersembunyi (dari unit ke-1 hingga ke-p; $\mathrm{i}=1 \ldots \mathrm{n} ; \mathrm{k}=1 \ldots \mathrm{m})$ dilakukan perhitungan informasi kesalahan lapisan tersembunyi $(\delta \mathrm{j})$. jj kemudian digunakan untuk menghitung besar koreksi bobot dan bias $(\Delta \mathrm{Vji}$ dan $\Delta \mathrm{Vjo})$ antara lapisan input dan lapisan tersembunyi.

- Langkah 8: \{Tahap III: Update bobot dan bias\}. Masingmasing unit output/keluaran (yk, $\mathrm{k}=1,2,3, \ldots, \mathrm{m})$ dilakukan update bias dan bobotnya $(j=0,1,2, \ldots p)$ sehingga menghasilkan bobot dan bias baru. Demikian juga untuk setiap unit tersembunyi mulai dari unit ke-1 sampai dengan unit ke-p dilakukan update bobot dan bias.

- Langkah 9: Uji kondisi berhenti (akhir iterasi).

G. Langkah-Langkah Penelitian

Penelitian dilakukan dengan sistematis dan alur yang baik agar didapatkan hasil yang sesuai dengan target sehingga dapat dijadikan bahan referensi bagi para peneliti lain. Adapun langkah yang dilakukan seperti terlihat pada kerangka kerja Gambar 2.

a) Pengumpulan Data

Pengumpulan data dilakukan untuk memperoleh informasi yang dibutuhkan dalam rangka mencapai tujuan penelitian. Data dikumpulkan dari sampel yang telah ditentukan sebelumnya. Sampel tersebut terdiri atas sekumpulan unit analisis sebagai sasaran penelitian.

b) Studi Pustaka

Untuk mencapai tujuan yang akan ditentukan, maka perlu dipelajari beberapa literatur-literatur yang digunakan. Studi pustaka merupakan langkah awal dalam penelitian ini, studi pustaka ini dilakukan untuk melengkapi pengetahuan dasar dan teori-teori yang digunakan dalam penelitian ini.

c) Identifikasi Masalah

Pada tahap identifikasi masalah ini, dilakukan setelah semua data-data terpenuhi kemudian didapatkan dataset yang sesuai untuk dilakukan proses pada tahap konversi data yang didapat sesuai dengan bobot yang ditentukan.

d) Pra proses

Tahap pra proses merupakan tahap seleksi data yang bertujuan untuk mendapatkan data yang bersih dan siap untuk digunakan dalam penelitian.

e) Pengujian Jaringan Saraf Tiruan

Setelah mendapatkan data yang cukup maka proses pengujian dan pelatihan data diolah dengan menggunakan algoritma Backpropagation.

f) Penentuan Model

Pada tahap ini akan dilakukan penentuan model jaringan syaraf tiruan dengan metode Backpropagation. Hasil dari tahap ini adalah untuk mendapatkan pola yang terbaik jaringan syaraf tiruan dengan metode Backpropagation.

g) Pengujian Hasil Pengolahan Data

Setelah proses penentuan model selesai, maka dilakukan tahapan uji coba terhadap hasil pengolahan data dari hasil desain program. Apakah desain program yang dibuat telah sesuai dengan apa yang diharapkan.

h) Evaluasi Akhir

Evaluasi akhir dilakukan untuk mengetahui apakah sistem yang dirancang tersebut sesuai dengan yang diharapkan. Evaluasi dilakukan untuk membandingkan hasil yang diharapkan pada tahap implementasin sistem yang dibuat secara manual dengan sistem yang dibuat menggunakan software Matlab.

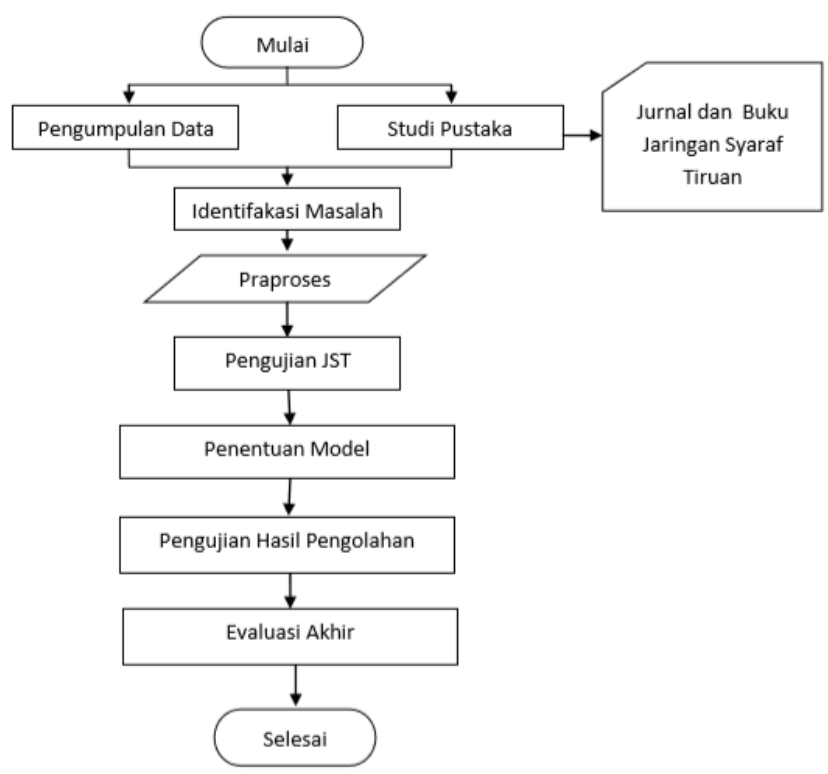

Gambar 2. Langkah-Langkah Penelitian. 


\section{HASIL DAN PEMBAHASAN}

A. Perancangan Sistem

a) Pendefenisian Input dan Target

Data ketersediaan tanaman cabai berdasarkan provinsi di Indonesia akan diolah oleh Jaringan Saraf Tiruan dengan metode backpropogation. Agar data dapat dikenali oleh Jaringan Saraf Tiruan, maka data harus direpresentasikan ke dalam bentuk numerik antara 0 sampai dengan 1, baik variabel maupun isinya yang merupakan masukan data ketersediaan tanaman cabai berdasarkan provinsi di Indonesia sebagai pengenalan pola dan keluaran yang merupakan prediksi yang diperoleh dari model arsitektur terbaik pada saat penentuan pola terbaik. Hal ini dikarenakan jaringan menggunakan fungsi aktivasi sigmoid biner (logsig) dengan range dari 0 sampai 1 . Nilai-nilai yang digunakan diperoleh berdasarkan kategori dari masing-masing variabel selain juga untuk memudahkan mengingat dalam pendefinisiannya.

\section{b) Pendefenisian Input}

Variabel ketersediaan tanaman cabai berdasarkan provinsi di Indonesia adalah kriteria yang menjadi acuan dalam pengambilan keputusan pada penilaian dengan menggunakan Jaringan Saraf Tiruan. Variabel ditentukan dengan cara melihat ketergantungan data terhadap penelitian yang dilakukan. Kriteria yang digunakan berdasarkan Data Badan Pusat Statistik Nasional dari website URL: www.bps.go.id. Adapun daftar variabel dalam memprediksi ketersediaan tanaman cabai berdasarkan provinsi di Indonesia disajikan pada Tabel 1 .

Tabel 1. Daftar Kriteria Ketersediaan Tanaman Cabai Berdasarkan Provinsi di Indonesia.

\begin{tabular}{rll}
\hline No & Variabel & Nama Kriteria \\
\hline 1 & X1 & Tahun 2012 \\
\hline 2 & X2 & Tahun 2013 \\
\hline 3 & X3 & Tahun 2014 \\
\hline 4 & X4 & Tahun 2015 \\
\hline
\end{tabular}

Sumber : Badan Pusat Statistik Nasional

Data input diperoleh dari website Badan Pusat Statistik Nasional tentang ketersediaan tanaman cabai berdasarkan provinsi di Indonesia. Data sampel yang digunakan adalah Ketersediaan Tanaman Cabai Berdasarkan Provinsi di Indonesia Berdasarkan Propinsi Tahun 2012 sampai Tahun 2017 yang terdiri dari 32 data lengkap dan masing-masing data memiliki 4 variabel dan 1 target. Data ini nantinya akan ditransformasikan ke sebuah data antara 0 sampai 1 sebelum dilakukan pelatihan dan pengujian menggunakan Jaringan Saraf Tiruan metode backpropagation dengan rumus:

$x^{\prime}=\frac{0,8(x-x \min )}{x \cdot \max -x \cdot \min }+0,1$

c) Pendefenisian Target
Adapun data target adalah Ketersediaan Tanaman Cabai Berdasarkan Provinsi di Indonesia Tahun 2017.

d) Pendefenisian Output

Hasil yang diharapkan pada tahap pendefenisian ini adalah untuk mencari pola menentukan nilai terbaik untuk memprediksi produksi cabai. Hasil pengujian berfungsi sebagai berikut :

- Untuk mengetahui prediksi produksi cabai yang didasarkan pada data produksi cabai berdasarkan provinsi. Output dari prediksi ini adalah pola arsitektur terbaik untuk memprediksi produksi cabai dengan melihat error minimum.

- Kategorisasi output pelatihan (train) dan pengujian (test) Kategori untuk output ditentukan oleh tingkat error minimum dari target. Batasan kategori tersebut terdapat pada Tabel 2 berikut:

Tabel 2. Data Kategorisasi.

\begin{tabular}{rlr}
\hline No & Keterangan & Error Minimum \\
\hline 1 & Benar & $0,001-0,05$ \\
\hline 2 & Salah & $>0,05$ \\
\hline
\end{tabular}

\section{B. Pengolahan Data}

Pengolahan data dilakukan dengan bantuan Matlab R2011A aplikasi perangkat lunak. Sampel data adalah produksi cabai berdasarkan provinsi. Data ini akan digunakan pada data pelatihan dan data pengujian. Sampel data yang telah diproses dan ditranformasikan disajikan pada Tabel 3 dan Tabel 4 sebagai berikut:

Tabel 3. Data Mentah.

\begin{tabular}{|c|c|c|c|c|c|c|}
\hline \multirow{2}{*}{ No } & \multirow{2}{*}{ Nama } & \multicolumn{4}{|c|}{ Variabel } & \multirow{2}{*}{$\begin{array}{c}\text { Target } \\
\mathbf{T}\end{array}$} \\
\hline & & X1 & $\mathbf{X} 2$ & $\mathbf{X 3}$ & $\mathrm{X} 4$ & \\
\hline 1 & Aceh & 51412 & 42427 & 50188 & 52907 & 45449 \\
\hline 2 & $\begin{array}{l}\text { Sumatera } \\
\text { Utara }\end{array}$ & 197411 & 161933 & 147812 & 187835 & 152629 \\
\hline 3 & $\begin{array}{l}\text { Sumatera } \\
\text { Barat }\end{array}$ & 57673 & 60981 & 59390 & 63403 & 68226 \\
\hline 4 & Riau & 9956 & 9089 & 9356 & 7393 & 12003 \\
\hline 5 & Jambi & 10523 & 39055 & 36715 & 30341 & 39523 \\
\hline 6 & $\begin{array}{l}\text { Sumatera } \\
\text { Selatan }\end{array}$ & 18059 & 15109 & 14074 & 10138 & 26489 \\
\hline 7 & Bengkulu & 30337 & 40001 & 46167 & 41367 & 35773 \\
\hline 8 & Lampung & 42439 & 35233 & 32259 & 31274 & 34790 \\
\hline 9 & $\begin{array}{l}\text { Kep. } \\
\text { Bangka } \\
\text { Belitung }\end{array}$ & 3230 & 3636 & 3686 & 2517 & 2280 \\
\hline 10 & Kep. Riau & 2236 & 1852 & 3434 & 2389 & 1960 \\
\hline 11 & Jawa Barat & 201383 & 250914 & 253296 & 240865 & 242114 \\
\hline 12 & $\begin{array}{l}\text { Jawa } \\
\text { Tengah }\end{array}$ & 130129 & 145037 & 167795 & 168412 & 164980 \\
\hline
\end{tabular}




\begin{tabular}{|c|c|c|c|c|c|c|}
\hline 13 & $\begin{array}{l}\text { DI } \\
\text { Yogyakarta }\end{array}$ & 16460 & 17134 & 17760 & 23389 & 24484 \\
\hline 14 & Jawa Timur & 99674 & 101691 & 111022 & 91135 & 95541 \\
\hline 15 & Banten & 6344 & 5841 & 6798 & 6608 & 8404 \\
\hline 16 & Bali & 13786 & 15430 & 20349 & 14138 & 12966 \\
\hline 17 & $\begin{array}{l}\text { Nusa } \\
\text { Tenggara } \\
\text { Barat }\end{array}$ & 7183 & 6398 & 20652 & 11227 & 12041 \\
\hline 18 & $\begin{array}{l}\text { Nusa } \\
\text { Tenggara } \\
\text { Timur }\end{array}$ & 2389 & 1916 & 1709 & 1279 & 1769 \\
\hline 19 & $\begin{array}{l}\text { Kalimantan } \\
\text { Barat }\end{array}$ & 2106 & 2848 & 2201 & 2130 & 2912 \\
\hline 20 & $\begin{array}{l}\text { Kalimantan } \\
\text { Tengah }\end{array}$ & 747 & 1013 & 944 & 642 & 614 \\
\hline 21 & $\begin{array}{l}\text { Kalimantan } \\
\text { Selatan }\end{array}$ & 5492 & 5094 & 7418 & 5904 & 8817 \\
\hline 22 & $\begin{array}{l}\text { Kalimantan } \\
\text { Timur }\end{array}$ & 5361 & 6471 & 8008 & 5096 & 3367 \\
\hline 23 & $\begin{array}{l}\text { Sulawesi } \\
\text { Utara }\end{array}$ & 996 & 2826 & 5451 & 5748 & 3571 \\
\hline 24 & $\begin{array}{l}\text { Sulawesi } \\
\text { Tengah }\end{array}$ & 3013 & 3072 & 5813 & 5436 & 4756 \\
\hline 25 & $\begin{array}{l}\text { Sulawesi } \\
\text { Selatan }\end{array}$ & 22582 & 27059 & 28007 & 23780 & 27639 \\
\hline 26 & $\begin{array}{l}\text { Sulawesi } \\
\text { Tenggara }\end{array}$ & 4381 & 2846 & 3349 & 1798 & 2560 \\
\hline 27 & Gorontalo & 371 & 419 & 303 & 222 & 152 \\
\hline 28 & $\begin{array}{l}\text { Sulawesi } \\
\text { Barat }\end{array}$ & 1919 & 1352 & 1278 & 891 & 1192 \\
\hline 29 & Maluku & 1451 & 2163 & 1890 & 2011 & 1443 \\
\hline 30 & $\begin{array}{l}\text { Maluku } \\
\text { Utara }\end{array}$ & 578 & 1126 & 4129 & 1595 & 1351 \\
\hline 31 & Papua Barat & 1093 & 234 & 270 & 281 & 837 \\
\hline 32 & Papua & 3649 & 2679 & 3088 & 1954 & 2889 \\
\hline
\end{tabular}

Sumber : Diolah dari Badan Pusat Statistik (www.bps.go.id)

Tabel 4. Sampel Dari Data yang Telah Ditransformasikan.

\begin{tabular}{ccccccc}
\multirow{2}{*}{ No } & Nama & \multicolumn{5}{c}{ Variabel } \\
\cline { 3 - 7 } & & $\mathbf{X 1}$ & $\mathbf{X 2}$ & $\mathbf{X 3}$ & $\mathbf{X 4}$ & $\mathbf{T}$ \\
$\mathbf{1}$ & Data 1 & 0,2497 & 0,2235 & 0,2461 & 0,2541 & 0,2323 \\
\hline $\mathbf{2}$ & Data 2 & 0,6756 & 0,5721 & 0,5309 & 0,6477 & 0,5450 \\
\hline $\mathbf{3}$ & Data 3 & 0,2680 & 0,2776 & 0,2730 & 0,2847 & 0,2988 \\
\hline $\mathbf{4}$ & Data 4 & 0,1288 & 0,1262 & 0,1270 & 0,1213 & 0,1347 \\
\hline $\mathbf{5}$ & Data 5 & 0,1304 & 0,2136 & 0,2068 & 0,1882 & 0,2150 \\
\hline $\mathbf{6}$ & Data 6 & 0,1524 & 0,1438 & 0,1408 & 0,1293 & 0,1770 \\
\hline $\mathbf{7}$ & Data 7 & 0,1882 & 0,2164 & 0,2344 & 0,2204 & 0,2041 \\
\hline $\mathbf{8}$ & Data 8 & 0,2235 & 0,2025 & 0,1938 & 0,1909 & 0,2012 \\
\hline $\mathbf{9}$ & Data 9 & 0,1091 & 0,1103 & 0,1105 & 0,1071 & 0,1064 \\
\hline $\mathbf{1 0}$ & Data 10 & 0,1062 & 0,1051 & 0,1097 & 0,1067 & 0,1054 \\
\hline $\mathbf{1 1}$ & Data 11 & 0,6872 & 0,8317 & 0,8387 & 0,8024 & 0,8061 \\
\hline
\end{tabular}

\begin{tabular}{lllllll}
\hline $\mathbf{1 2}$ & Data 12 & 0,4794 & 0,5228 & 0,5892 & 0,5910 & 0,5810 \\
\hline $\mathbf{1 3}$ & Data 13 & 0,1477 & 0,1497 & 0,1515 & 0,1679 & 0,1711 \\
\hline $\mathbf{1 4}$ & Data 14 & 0,3905 & 0,3964 & 0,4236 & 0,3656 & 0,3784 \\
\hline $\mathbf{1 5}$ & Data 15 & 0,1182 & 0,1167 & 0,1195 & 0,1190 & 0,1242 \\
\hline $\mathbf{1 6}$ & Data 16 & 0,1399 & 0,1447 & 0,1591 & 0,1410 & 0,1375 \\
\hline $\mathbf{1 7}$ & Data 17 & 0,1207 & 0,1184 & 0,1600 & 0,1325 & 0,1348 \\
\hline $\mathbf{1 8}$ & Data 18 & 0,1067 & 0,1053 & 0,1047 & 0,1034 & 0,1049 \\
\hline $\mathbf{1 9}$ & Data 19 & 0,1059 & 0,1080 & 0,1061 & 0,1059 & 0,1082 \\
\hline $\mathbf{2 0}$ & Data 20 & 0,1019 & 0,1027 & 0,1025 & 0,1016 & 0,1015 \\
\hline $\mathbf{2 1}$ & Data 21 & 0,1157 & 0,1146 & 0,1213 & 0,1169 & 0,1254 \\
\hline $\mathbf{2 2}$ & Data 22 & 0,1153 & 0,1186 & 0,1231 & 0,1146 & 0,1095 \\
\hline $\mathbf{2 3}$ & Data 23 & 0,1026 & 0,1080 & 0,1156 & 0,1165 & 0,1101 \\
\hline $\mathbf{2 4}$ & Data 24 & 0,1085 & 0,1087 & 0,1167 & 0,1156 & 0,1136 \\
\hline $\mathbf{2 5}$ & Data 25 & 0,1656 & 0,1787 & 0,1814 & 0,1691 & 0,1803 \\
\hline $\mathbf{2 6}$ & Data 26 & 0,1125 & 0,1080 & 0,1095 & 0,1050 & 0,1072 \\
\hline $\mathbf{2 7}$ & Data 27 & 0,1008 & 0,1009 & 0,1006 & 0,1004 & 0,1002 \\
\hline $\mathbf{2 8}$ & Data 28 & 0,1053 & 0,1037 & 0,1034 & 0,1023 & 0,1032 \\
\hline $\mathbf{2 9}$ & Data 29 & 0,1039 & 0,1060 & 0,1052 & 0,1056 & 0,1039 \\
\hline $\mathbf{3 0}$ & Data 30 & 0,1014 & 0,1030 & 0,1118 & 0,1044 & 0,1036 \\
\hline $\mathbf{3 1}$ & Data 31 & 0,1029 & 0,1004 & 0,1005 & 0,1005 & 0,1022 \\
\hline $\mathbf{3 2}$ & Data 32 & 0,1104 & 0,1075 & 0,1087 & 0,1054 & 0,1081 \\
\hline & & & & & & \\
\hline
\end{tabular}

C. Perancangan Arsitektur Jaringan Syaraf Tiruan

Jaringan yang digunakan untuk dalam memprediksi ketersediaan tanaman cabai berdasarkan provinsi di Indonesia dengan backpropogation dengan langkah pembelajaran feedforward. Jaringan ini memiliki beberapa lapisan, yaitu lapisan masukan (input), lapisan keluaran (output), dan beberapa lapisan tersembunyi (hidden). Lapisan tersembunyi tersebut membantu jaringan untuk dapat mengenali lebih banyak pola masukan dibandingkan dengan jaringan yang tidak memiliki lapisan tersembunyi. Parameter-parameter dalam pembentukan jaringan backpropagation menggunakan 4 variabel masukan, 1 lapisan tersembunyi, dan 1 lapisan keluaran. Adapun model arsitektur yang digunakan untuk mendapatkan arsitektur terbaik adalah 4-2-1, 4-3-1, 4-4-1, dan 4-5-1.

Jaringan syaraf yang akan dibangun adalah algoritma propagasi balik (backpropagation) dengan fungsi aktivasi Sigmoid. Fungsi aktivasi dalam Jaringan Saraf Tiruan dipakai untuk proses perhitungan terhadap nilai aktual output pada hidden layer dan menghitung nilai aktual output pada output layer.

Tahapan-tahapan yang akan dilakukan dalam pengguna algoritma propagasi balik dengan fungsi aktivasi sigmoid. Tahapan yang harus dilakukan adalah sebagi berikut:

- Inisialisasi (initialization), merupakan tahap di mana variabel-variabel nilai akan didefinisikan terlebih dahulu, misalnya seperti: nilai data input, weight, nilai output 
yang diharapkan, learning rate, dan nilai-nilai data lainnya.

- Aktivasi (activation), merupakan proses perhitungan terhadap nilai aktual output pada hidden layer dan menghitung nilai actual output pada output layer.

- Weight Training, merupakan proses perhitungan nilai error gradient pada output layer dan menghitung nilai error gradient pada hidden layer

- Iteration, merupakan tahap akhir dalam penggujian, dimana jika masih terjadi error minimum yang diharapkan belum ditemukan maka kembali pada tahap aktivasi (activation).

Arsitektur yang digunakan pada jaringan syaraf tiruan ini memiliki karakteristik arsitektur jaringan sebagai berikut :

Tabel 5. Arsitektur Jaringan.

\begin{tabular}{ll}
\multicolumn{1}{c}{ Karakteristik } & \multicolumn{1}{c}{ Spesifikasi } \\
Arsitektur & 1 hidden layer \\
\hline Hidden Layer & $2,3,4,5$ \\
\hline Input Data & 4 \\
\hline Output Data & 1 \\
\hline Training Function & Traingd \\
\hline Activation Function & Sigmoid \\
\hline Goal & 0,001 \\
\hline Maximum Epoch & 1000000 \\
\hline Learning Rate & 0,01 \\
\hline
\end{tabular}

a) Pelatihan dan Pengujian Arsitektur 4-2-1

Data ketersediaan tanaman cabai berdasarkan propinsi terdiri dari 32 data. Berikut adalah hasil pelatihan data dan pengujian dengan pola pengujian 4-2-1. Data hasil pengujian dan pelatihan dapat dilihat pada Tabel 6 sebagai berikut:

Tabel 6. Pelatihan dan Pengujian Model 4-2-1.

\begin{tabular}{|c|c|c|c|c|c|c|c|}
\hline \multicolumn{4}{|c|}{ Pelatihan (Train) } & \multicolumn{4}{|c|}{ Pengujian (Test) } \\
\hline No Target & $\begin{array}{l}\text { Output } \\
\text { JST }\end{array}$ & Error & SSE & No Target & $\begin{array}{c}\text { Output } \\
\text { JST }\end{array}$ & Error & SSE \\
\hline 10,2323 & 0,3010 & $0,0687^{-}$ & 0,00472 & 10,2545 & 0,2782 & $0,0237^{-}$ & 0,00056169 \\
\hline 20,5450 & 0,4536 & 0,0914 & 0,008354 & 20,5640 & 0,4353 & 0,1287 & 0,01656369 \\
\hline 30,2988 & 0,3216 & $0,0228^{-}$ & 0,00052 & 30,3783 & 0,3225 & 0,0558 & 0,00311364 \\
\hline 40,1347 & 0,2019 & 0,0672 & 0,004516 & 40,1458 & 0,2019 & 0,0561 & 0,00314721 \\
\hline 50,2150 & 0,1948 & 0,0202 & 0,000408 & $\begin{array}{ll}5 & 0,1918\end{array}$ & 0,2909 & $0,0991^{-}$ & 0,00982081 \\
\hline 60,1770 & 0,2288 & $0,051 \overline{8}^{-}$ & 0,002683 & 60,2178 & 0,1741 & 0,0437 & 0,00190969 \\
\hline 70,2041 & 0,2383 & $0,0342^{-}$ & 0,00117 & 70,1935 & 0,1689 & 0,0246 & 0,00060516 \\
\hline 80,2012 & 0,3004 & $0,0992^{-}$ & 0,009841 & 80,2462 & 0,1645 & 0,0817 & 0,00667489 \\
\hline 90,1064 & 0,1833 & 0,0769 & 0,005914 & 90,1055 & 0,1869 & $0,0814^{-}$ & 0,00662596 \\
\hline 100,1054 & 0,1782 & 0,0728 & 0,0053 & 100,1054 & 0,1811 & $0,0757^{-}$ & 0,00573049 \\
\hline 110,8061 & 0,4170 & 0,3891 & 0,151399 & 110,9000 & 0,4367 & 0,4633 & 0,21464689 \\
\hline 120,5810 & 0,3901 & 0,1909 & 0,036443 & 120,6703 & 0,4103 & 0,2600 & 0,0676 \\
\hline 130,1711 & 0,2159 & $0,0448^{-}$ & 0,002007 & 130,1858 & 0,2083 & $0,0225^{-}$ & 0,00050625 \\
\hline
\end{tabular}

\begin{tabular}{|c|c|c|c|c|c|c|}
\hline $14 \quad 0,3784$ & 0,3859 & $0,0075^{5,63 \mathrm{E}-05}$ & $14 \quad 0,3943$ & 0,4022 & 0,0079 & 0,00006241 \\
\hline 150,1242 & 0,1901 & $0,0659^{0,004343}$ & $15 \quad 0,1186$ & 0,1897 & 0,0711 & 0,00505521 \\
\hline 160,1375 & 0,2016 & $0,0641^{-0,004109}$ & 160,1368 & 0,2260 & $0,0892^{-}$ & 0,00795664 \\
\hline 170,1348 & 0,1678 & $0,0330^{-0,001089}$ & 170,1925 & 0,2027 & $0,0102^{-}$ & 0,00010404 \\
\hline $18 \quad 0,1049$ & 0,1822 & $0,0773^{-0,005975}$ & $18 \quad 0,1069$ & 0,1810 & $0,0741^{-}$ & 0,00549081 \\
\hline 190,1082 & 0,1815 & $0,0733^{-} 0,005373$ & 190,1046 & 0,1829 & $0,0783^{-}$ & 0,00613089 \\
\hline 200,1015 & 0,1771 & $0,0756^{-0,005715}$ & 200,1016 & 0,1785 & $0,0769^{-}$ & 0,00591361 \\
\hline 210,1254 & 0,1853 & $0,0599^{-} 0,003588$ & 210,1299 & 0,1895 & $0,0596^{-}$ & 0,00355216 \\
\hline 220,1095 & 0,1858 & $0,0763^{-0,005822}$ & 220,1099 & 0,1974 & 0,0875 & 0,00765625 \\
\hline 230,1101 & 0,1714 & $0,0613^{-0,003758}$ & 230,1139 & 0,1807 & 0,0668 & 0,00446224 \\
\hline 240,1136 & 0,1775 & $0,0639^{-0,004083}$ & $24 \quad 0,1192$ & 0,1823 & $0,0631^{-}$ & 0,00398161 \\
\hline 250,1803 & 0,2314 & $0,0511^{-0,002611}$ & $25 \quad 0,1939$ & 0,2548 & 0,0609 & 0,00370881 \\
\hline 260,1072 & 0,1869 & $0,0797^{-0,006352}$ & 260,1032 & 0,1851 & $0,0819^{-}$ & 0,00670761 \\
\hline 270,1002 & 0,1763 & $0,0761^{-0,005791}$ & 270,1003 & 0,1764 & 0,0761 & 0,00579121 \\
\hline 280,1032 & 0,1808 & $0,0776^{-0,006022}$ & 280,1051 & 0,1795 & $0,0744^{-}$ & 0,00553536 \\
\hline 290,1039 & 0,1789 & $0,0750^{-0,005625}$ & 290,1044 & 0,1808 & 0,0764 & 0,00583696 \\
\hline 300,1036 & 0,1709 & $0,0673^{-0,004529}$ & $30 \quad 0,1037$ & 0,1813 & $0,077 \overline{6}^{-}$ & \\
\hline 310,1022 & 0,1785 & $0,0763^{-0,005822}$ & 310,1000 & 0,1757 & $0,0757^{-}$ & 0,00573049 \\
\hline 320,1081 & 0,1847 & $0,0766^{-0,005868}$ & 320,1069 & 0,1839 & $0,0770^{-}$ & 0,005929 \\
\hline Total & & 0,319804 & Total & & & 0,43313344 \\
\hline \multirow[t]{2}{*}{ MSE } & & 0,009994 & MSE & & & 0,01353542 \\
\hline & & & \multicolumn{3}{|c|}{ Akurasi Kebenaran (\%) } & $93,75 \%$ \\
\hline
\end{tabular}

b) Pelatihan dan Pengujian Arsitektur 5-12-1

Berikut ini adalah hasil pelatihan dan pengujian data menggunakan arsitektur 4-3-1. Data hasil pelatihan dan pengujian dapat dilihat sebagai berikut :

Tabel 7. Pelatihan dan Pengujian Model 4-3-1.

\begin{tabular}{cccccccccccc}
\multicolumn{4}{c}{ Pelatihan (Train) } & \multicolumn{6}{c}{ Pengujian (Test) } \\
\hline No & Target & Output & EST & Error & SSE & No & Target & Output JST & Error & SSE \\
\hline $\mathbf{1}$ & 0,2323 & 0,0885 & 0,1438 & 0,020678 & 1 & 0,2545 & 0,0883 & 0,1662 & 0,027622 \\
\hline $\mathbf{2}$ & 0,5450 & 0,6708 & $-0,1258$ & 0,015826 & 2 & 0,5640 & 0,2889 & 0,2751 & 0,07568 \\
\hline $\mathbf{3}$ & 0,2988 & 0,0891 & 0,2097 & 0,043974 & 3 & 0,3783 & 0,0899 & 0,2884 & 0,083175 \\
\hline $\mathbf{4}$ & 0,1347 & 0,0889 & 0,0458 & 0,002098 & 4 & 0,1458 & 0,0895 & 0,0563 & 0,00317 \\
\hline $\mathbf{5}$ & 0,2150 & 0,0910 & 0,1240 & 0,015376 & 5 & 0,1918 & 0,0880 & 0,1038 & 0,010774 \\
\hline $\mathbf{6}$ & 0,1770 & 0,0878 & 0,0892 & 0,007957 & 6 & 0,2178 & 0,0922 & 0,1256 & 0,015775 \\
\hline $\mathbf{7}$ & 0,2041 & 0,0900 & 0,1141 & 0,013019 & 7 & 0,1935 & 0,0931 & 0,1004 & 0,01008 \\
\hline $\mathbf{8}$ & 0,2012 & 0,0862 & 0,1150 & 0,013225 & 8 & 0,2462 & 0,0933 & 0,1529 & 0,023378 \\
\hline $\mathbf{9}$ & 0,1064 & 0,0894 & 0,0170 & 0,000289 & 9 & 0,1055 & 0,0892 & 0,0163 & 0,000266 \\
\hline $\mathbf{1 0}$ & 0,1054 & 0,0896 & 0,0158 & 0,00025 & 10 & 0,1054 & 0,0894 & 0,0160 & 0,000256 \\
\hline
\end{tabular}




\begin{tabular}{|c|c|c|c|c|c|c|c|c|c|}
\hline 11 & 0,8061 & 0,8090 & $-0,0029$ & $8,41 \mathrm{E}-06$ & 11 & 0,9000 & 0,8017 & 0,0983 & 0,009663 \\
\hline 12 & 0,5810 & 0,2956 & 0,2854 & 0,081453 & 12 & 0,6703 & 0,4004 & 0,2699 & 0,072846 \\
\hline 13 & 0,1711 & 0,0898 & 0,0813 & 0,00661 & 13 & 0,1858 & 0,0900 & 0,0958 & 0,009178 \\
\hline 14 & 0,3784 & 0,0950 & 0,2834 & 0,080316 & 14 & 0,3943 & 0,1022 & 0,2921 & 0,085322 \\
\hline 15 & 0,1242 & 0,0894 & 0,0348 & 0,001211 & 15 & 0,1186 & 0,0896 & 0,0290 & 0,000841 \\
\hline 16 & 0,1375 & 0,0891 & 0,0484 & 0,002343 & 16 & 0,1368 & 0,0883 & 0,0485 & 0,002352 \\
\hline 17 & 0,1348 & 0,0903 & 0,0445 & 0,00198 & 17 & 0,1925 & 0,0893 & 0,1032 & 0,01065 \\
\hline 18 & 0,1049 & 0,0894 & 0,0155 & 0,00024 & 18 & 0,1069 & 0,0895 & 0,0174 & 0,000303 \\
\hline 19 & 0,1082 & 0,0895 & 0,0187 & 0,00035 & 19 & 0,1046 & 0,0895 & 0,0151 & 0,000228 \\
\hline 20 & 0,1015 & 0,0895 & 0,0120 & 0,000144 & 20 & 0,1016 & 0,0895 & 0,0121 & 0,000146 \\
\hline 21 & 0,1254 & 0,0895 & 0,0359 & 0,001289 & 21 & 0,1299 & 0,0897 & 0,0402 & 0,001616 \\
\hline 22 & 0,1095 & 0,0893 & 0,0202 & 0,000408 & 22 & 0,1099 & 0,0888 & 0,0211 & 0,000445 \\
\hline 23 & 0,1101 & 0,0901 & 0,0200 & 0,0004 & 23 & 0,1139 & 0,0895 & 0,0244 & 0,000595 \\
\hline 24 & 0,1136 & 0,0898 & 0,0238 & 0,000566 & 24 & 0,1192 & 0,0896 & 0,0296 & 0,000876 \\
\hline 25 & 0,1803 & 0,0887 & 0,0916 & 0,008391 & 25 & 0,1939 & 0,0884 & 0,1055 & 0,01113 \\
\hline 26 & 0,1072 & 0,0892 & 0,0180 & 0,000324 & 26 & 0,1032 & 0,0894 & 0,0138 & 0,00019 \\
\hline 27 & 0,1002 & 0,0896 & 0,0106 & 0,000112 & 27 & 0,1003 & 0,0895 & 0,0108 & 0,000117 \\
\hline 28 & 0,1032 & 0,0894 & 0,0138 & 0,00019 & 28 & 0,1051 & 0,0895 & 0,0156 & 0,000243 \\
\hline 29 & 0,1039 & 0,0896 & 0,0143 & 0,000204 & 29 & 0,1044 & 0,0894 & 0,0150 & 0,000225 \\
\hline 30 & 0,1036 & 0,0898 & 0,0138 & 0,00019 & 30 & 0,1037 & 0,0894 & 0,0143 & 0,000204 \\
\hline 31 & 0,1022 & 0,0895 & 0,0127 & 0,000161 & 31 & 0,1000 & 0,0896 & 0,0104 & 0,000108 \\
\hline 32 & 0,1081 & 0,0893 & 0,0188 & 0,000353 & 32 & 0,1069 & 0,0895 & 0,0174 & 0,000303 \\
\hline Tot & & & & 0,319936 & \multicolumn{4}{|c|}{ Total } & 0,45776 \\
\hline MS & & & & 0,009998 & \multicolumn{4}{|c|}{ MSE } & 0,014305 \\
\hline
\end{tabular}

c) Pelatihan dan Pengujian Arsitektur 4-4-1

Berikut ini adalah hasil pelatihan dan pengujian data menggunakan arsitektur 4-4-1. Data hasil pelatihan dan pengujian dapat dilihat sebagai berikut :

Tabel 8. Pelatihan dan Pengujian Model 4-4-1.

\begin{tabular}{|c|c|c|c|c|c|c|c|}
\hline \multicolumn{4}{|c|}{ Pelatihan (Train) } & \multicolumn{4}{|c|}{ Pengujian (Test) } \\
\hline No Target & Output JST & Error & SSE & No Target & Output JST & Error & SSE \\
\hline 10,2323 & 0,0867 & 0,14562 & 0,021205 & 10,2545 & 0,0956 & 0,1589 & 0,02524 \\
\hline 20,5450 & 0,5723 & 0,02732 & 0,000746 & 20,5640 & 0,5633 & 0,0007 & $4,9 \mathrm{E}-0$ \\
\hline 30,2988 & 0,1071 & 0,19173 & 0,03676 & $\begin{array}{ll}3 & 0,3783\end{array}$ & 0,1071 & 0,2712 & 0,0735 \\
\hline 40,1347 & 0,0440 & 0,09069 & 0,008225 & $\begin{array}{ll}4 & 0,1458\end{array}$ & 0,0389 & 0,1069 & 0,0114 \\
\hline 50,2150 & 0,0558 & (150015 & 0,025351 & $\begin{array}{ll}5 & 0,1918\end{array}$ & 0,0674 & 0,1 & 0,0154 \\
\hline 60,1770 & 0,0539 & 0,12307 & 0,015146 & $\begin{array}{ll}6 & 0,2178\end{array}$ & 0,0285 & 0.1803 & 0,03583 \\
\hline 70,2041 & 0,0697 & 0,13435 & 0,01805 & 70,1935 & 0,0497 & 0,1438 & 0,02067 \\
\hline $\begin{array}{ll}8 & 0,2012\end{array}$ & 0,0841 & 0,11705 & 0,013701 & $\begin{array}{ll}8 & 0,2462\end{array}$ & 0,0378 & 0,2084 & 0,04343 \\
\hline 90,1064 & 0,0384 & & 0,004621 & 90,1055 & 0,0383 & 8,0012 & $0,00+5$ \\
\hline
\end{tabular}

\begin{tabular}{|c|c|c|c|c|}
\hline 10 & 0,1054 & $\begin{array}{lll}0,0371 & 0,06828 & 0,004662\end{array}$ & 100,1054 & $\begin{array}{llll}0,0374 & 0,0680 & 0,004624\end{array}$ \\
\hline 11 & 0,8061 & $\begin{array}{llll}0,6863 & 0,11980 & 0,014352\end{array}$ & 110,9000 & $0,73090,16910,028595$ \\
\hline 12 & 0,5810 & $\begin{array}{llll}0,4397 & 0,14133 & 0,019974\end{array}$ & 120,6703 & $\begin{array}{llll}0,4933 & 0,1770 & 0,031329\end{array}$ \\
\hline 13 & 0,1711 & $\begin{array}{llll}0,0432 & 0,12795 & 0,016371\end{array}$ & 130,1858 & $\begin{array}{llll}0,0460 & 0,1398 & 0,019544\end{array}$ \\
\hline 14 & 0,3784 & $\begin{array}{llll}0,2585 & 0,11993 & 0,014383\end{array}$ & 140,3943 & $\begin{array}{llll}0,2352 & 0,1591 & 0,025313\end{array}$ \\
\hline 15 & 0,1242 & $\begin{array}{llll}0,0395 & 0,08468 & 0,007171\end{array}$ & 150,1186 & $\begin{array}{llll}0,0382 & 0,0804 & 0,006464\end{array}$ \\
\hline 16 & 0,1375 & $\begin{array}{lll}0,0503 & 0,08725 & 0,007613\end{array}$ & 160,1368 & $\begin{array}{llll}0,0519 & 0,0849 & 0,007208\end{array}$ \\
\hline 17 & 0,1348 & $\begin{array}{llll}0,0436 & 0,09121 & 0,008319\end{array}$ & 170,1925 & $\begin{array}{llll}0,0444 & 0,1481 & 0,021934\end{array}$ \\
\hline 18 & 0,1049 & $\begin{array}{llll}0,0373 & 0,06761 & 0,004571\end{array}$ & 180,1069 & $0,03640,0705$ \\
\hline 19 & 0,1082 & $\begin{array}{llll}0,0371 & 0,07108 & 0,005052\end{array}$ & 190,1046 & $0,03670,0679$ \\
\hline 20 & 0,1015 & $\begin{array}{llll}0,0362 & 0,06532 & 0,004267\end{array}$ & 200,1016 & $\begin{array}{llll}0,0362 & 0,0654 & 0,004277\end{array}$ \\
\hline 21 & 0,1254 & $\begin{array}{lll}0,0395 & 0,08586 & 0,007372\end{array}$ & 210,1299 & $\begin{array}{llll}0,0375 & 0,0924 & 0,008538\end{array}$ \\
\hline 22 & 0,1095 & $\begin{array}{llll}0,0410 & 0,06851 & 0,004694\end{array}$ & 220,1099 & $0,0424 \quad 0,06750,004556$ \\
\hline 23 & 0,1101 & $\begin{array}{llll}0,0354 & 0,07465 & 0,005573\end{array}$ & 230,1139 & $0,0392 \quad 0,0747$ \\
\hline 24 & 0,1136 & $\begin{array}{lll}0,0369 & 0,07667 & 0,005878\end{array}$ & 240,1192 & $\begin{array}{llll}0,0384 & 0,0808 & 0,006529\end{array}$ \\
\hline 25 & 0,1803 & $\begin{array}{llll}0,0601 & 0,12017 & 0,014441\end{array}$ & 250,1939 & $\begin{array}{llll}0,0578 & 0,1361 & 0,018523\end{array}$ \\
\hline 26 & 0,1072 & $\begin{array}{lll}0,0391 & 0,06807 & 0,004634\end{array}$ & 260,1032 & $\begin{array}{llll}0,0372 & 0,0660 & 0,004356\end{array}$ \\
\hline 27 & 0,1002 & $\begin{array}{llll}0,0358 & 0,06444 & 0,004153\end{array}$ & 270,1003 & $0,0358 \quad 0,0645$ \\
\hline 28 & 0,1032 & $\begin{array}{llll}0,0369 & 0,06631 & 0,004397\end{array}$ & 280,1051 & $\begin{array}{llll}0,0362 & 0,0689 & 0,004747\end{array}$ \\
\hline 29 & 0,1039 & $\begin{array}{llll}0,0364 & 0,06747 & 0,004552\end{array}$ & 290,1044 & $\begin{array}{llll}0,0372 & 0,0672 & 0,004516\end{array}$ \\
\hline 30 & 0,1036 & $\begin{array}{lll}0,0369 & 0,06675 & 0,004456\end{array}$ & $30 \quad 0,1037$ & 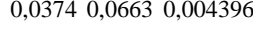 \\
\hline 31 & 0,1022 & $\begin{array}{lll}0,0360 & 0,06618 & 0,00438\end{array}$ & 310,1000 & $\begin{array}{llll}0,0352 & 0,0648 & 0,004199\end{array}$ \\
\hline 32 & 0,1081 & $\begin{array}{llll}0,0384 & 0,06969 & 0,004857\end{array}$ & 320,1069 & $\begin{array}{lll}0,0369 & 0,0700\end{array}$ \\
\hline Tota & & 0,319927 & Total & 0,46403 \\
\hline MSE & & 0,009998 & MSE & 0,014501 \\
\hline
\end{tabular}

d) Pelatihan dan Pengujian Arsitektur 4-5-1

Berikut ini adalah hasil pelatihan dan pengujian data menggunakan arsitektur 4-5-1. Data hasil pelatihan dan pengujian dapat dilihat sebagai berikut :

Tabel 9. Pelatihan dan Pengujian Model 4-5-1.

\begin{tabular}{r|cccccccccc}
\hline \multicolumn{4}{c}{ Pelatihan (Train) } & \multicolumn{6}{c}{ Pengujian (Test) } \\
\hline No & Target & $\begin{array}{c}\text { Output } \\
\text { JST }\end{array}$ & Error & SSE & No & Target & $\begin{array}{c}\text { Output } \\
\text { JST }\end{array}$ & Error & SSE \\
\hline $\mathbf{1}$ & 0,2323 & 0,2088 & 0,0235 & 0,000552 & 1 & 0,2545 & 0,1988 & 0,0557 & 0,003102 \\
\hline $\mathbf{2}$ & 0,5450 & 0,6995 & 0,1545 & 0,02387 & 2 & 0,5640 & 0,7568 & 0,1928 & 0,037172 \\
\hline $\mathbf{3}$ & 0,2988 & 0,3049 & 0,0061 & $-3,72 \mathrm{E}-05$ & 3 & 0,3783 & 0,3298 & 0,0485 & 0,002352 \\
\hline $\mathbf{4}$ & 0,1347 & 0,1418 & 0,0071 & $5,04 \mathrm{E}-05$ & 4 & 0,1458 & 0,1410 & 0,0048 & $2,3 \mathrm{E}-05$ \\
\hline $\mathbf{5}$ & 0,2150 & 0,1440 & 0,0710 & 0,005041 & 5 & 0,1918 & 0,1638 & 0,0280 & 0,000784 \\
\hline $\mathbf{6}$ & 0,1770 & 0,1421 & 0,0349 & 0,001218 & 6 & 0,2178 & 0,1343 & 0,0835 & 0,006972 \\
\hline $\mathbf{7}$ & 0,2041 & 0,1674 & 0,0367 & 0,001347 & 7 & 0,1935 & 0,1566 & 0,0369 & 0,001362 \\
\hline $\mathbf{8}$ & 0,2012 & 0,1602 & 0,0410 & 0,001681 & 8 & 0,2462 & 0,1422 & 0,1040 & 0,010816 \\
\hline $\mathbf{9}$ & 0,1064 & 0,1437 & 0,0373 & 0,001391 & 9 & 0,1055 & 0,1444 & 0,0389 & 0,001513 \\
\hline
\end{tabular}




\begin{tabular}{|c|c|c|c|c|c|c|c|c|c|}
\hline 10 & 0,1054 & 0,1443 & 0,0389 & 0,001513 & 10 & 0,1054 & 0,1437 & $0,0383^{-}$ & 0,001467 \\
\hline 11 & 0,8061 & 0,8186 & 0,0125 & 0,000156 & 11 & 0,9000 & 0,7175 & 0,1825 & 0,033306 \\
\hline 12 & 0,5810 & 0,9231 & $0,3421^{-}$ & 0,117032 & 12 & 0,6703 & 0,9013 & $0,2310^{-}$ & 0,053361 \\
\hline 13 & 0,1711 & 0,1395 & 0,0316 & 0,000999 & 13 & 0,1858 & 0,1394 & 0,0464 & 0,002153 \\
\hline 14 & 0,3784 & 0,7571 & 0,3787 & 0,143414 & 14 & 0,3943 & 0,7951 & $0,4008^{-}$ & 0,160641 \\
\hline 15 & 0,1242 & 0,1423 & $\begin{array}{r}- \\
0,0181\end{array}$ & 0,000328 & 15 & 0,1186 & 0,1413 & $\begin{array}{r}- \\
0,0227\end{array}$ & 0,000515 \\
\hline 16 & 0,1375 & 0,1380 & $\begin{array}{r}- \\
0,0005\end{array}$ & $2,5 \mathrm{E}-07$ & 16 & 0,1368 & 0,1387 & $0,0019^{-}$ & $3,61 \mathrm{E}-06$ \\
\hline 17 & 0,1348 & 0,1383 & 0,0035 & $1,23 \mathrm{E}-05$ & 17 & 0,1925 & 0,1346 & 0,0579 & 0,003352 \\
\hline 18 & 0,1049 & 0,1452 & 0,0403 & 0,001624 & 18 & 0,1069 & 0,1451 & $0,0382^{-}$ & 0,001459 \\
\hline 19 & 0,1082 & 0,1442 & $\begin{array}{r}- \\
0,0360\end{array}$ & 0,001296 & 19 & 0,1046 & 0,1447 & $\begin{array}{r}- \\
0,0401\end{array}$ & 0,001608 \\
\hline 20 & 0,1015 & 0,1453 & $0,0438^{-}$ & 0,001918 & 20 & 0,1016 & 0,1455 & 0,0439 & 0,001927 \\
\hline 21 & 0,1254 & 0,1422 & $0,0168^{-}$ & 0,000282 & 21 & 0,1299 & 0,1408 & $0,0109^{-}$ & 0,000119 \\
\hline 22 & 0,1095 & 0,1415 & $\begin{array}{r}- \\
0,0320\end{array}$ & 0,001024 & 22 & 0,1099 & 0,1427 & $\begin{array}{r}- \\
0,0328\end{array}$ & 0,001076 \\
\hline 23 & 0,1101 & 0,1417 & $0,031 \bar{r}^{-}$ & 0,000999 & 23 & 0,1139 & 0,1418 & 0,0279 & 0,000778 \\
\hline 24 & 0,1136 & 0,1425 & $\begin{array}{r}- \\
0,0289\end{array}$ & 0,000835 & 24 & 0,1192 & 0,1415 & 0,0223 & 0,000497 \\
\hline 25 & 0,1803 & 0,1410 & 0,0393 & 0,001544 & 25 & 0,1939 & 0,1449 & 0,0490 & 0,002401 \\
\hline 26 & 0,1072 & 0,1450 & $0,0378^{-}$ & 0,001429 & 26 & 0,1032 & 0,1443 & $\begin{array}{r}- \\
0,0411\end{array}$ & 0,001689 \\
\hline 27 & 0,1002 & 0,1457 & $\begin{array}{r}- \\
0,0455\end{array}$ & 0,00207 & 27 & 0,1003 & 0,1458 & $\begin{array}{r}- \\
0,0455\end{array}$ & 0,00207 \\
\hline 28 & 0,1032 & 0,1455 & 0,0423 & 0,001789 & 28 & 0,1051 & 0,1453 & 0,0402 & 0,001616 \\
\hline 29 & 0,1039 & 0,1443 & $\begin{array}{r}- \\
0,0404\end{array}$ & 0,001632 & 29 & 0,1044 & 0,1449 & $\begin{array}{r}- \\
0,0405\end{array}$ & 0,00164 \\
\hline 30 & 0,1036 & 0,1438 & $0,0402^{-}$ & 0,001616 & 30 & 0,1037 & 0,1435 & $0,0398^{-}$ & 0,001584 \\
\hline 31 & 0,1022 & 0,1462 & $0,0440^{-}$ & 0,001936 & 31 & 0,1000 & 0,1456 & 0,0456 & 0,002079 \\
\hline 32 & 0,1081 & 0,1448 & $0,0367^{-}$ & 0,001347 & 32 & 0,1069 & 0,1442 & 0,0373 & 0,001391 \\
\hline \multicolumn{4}{|c|}{ Total } & 0,320000 & \multicolumn{4}{|c|}{ Total } & 0,340832 \\
\hline \multicolumn{4}{|c|}{ MSE } & 0,010000 & \multicolumn{4}{|c|}{ MSE } & 0,010651 \\
\hline \multicolumn{9}{|c|}{ Akurasi Kebenaran (\%) } & $99,97 \%$ \\
\hline
\end{tabular}

e) Pelatihan dan Pengujian Arsitektur 5-18-1

Dari hasil pelatihan dan pengujian yang dilakukan, didapatkan hasil penilaian model arsitektur yang terbaik yang dapat dilihat dari berbagai aspek seperti akurasi, jumlah epochs dan error minimum. Untuk lebih jelasnya dapat dilihat pada gambar berikut:

Tabel 10. Rekapitulasi Model.

\begin{tabular}{crrrrr}
\hline Model & $4-2-1$ & $4-3-1$ & $4-4-1$ & $4-5-1$ \\
\hline Epochs & 523 & 293 & 1288 & 670 \\
\hline MSE & 0.01353542 & 0.014305 & 0.014501 & 0.010651 \\
\hline Akurasi & $93,75 \%$ & 87,50 & $93,75 \%$ & $99,97 \%$ \\
\hline
\end{tabular}

Dari tabel 10 dapat dilihat bahwa model arsitektur terbaik yang akan digunakan untuk melakukan prediksi dari serangkaian uji coba model adalah 4-5-1 dengan epoch 670, MSE 0.010651dan tingkat akurasi 99,97\%.

\section{KESIMPULAN}

Berdasarkan hasil dan pembahasan diatas, maka penulis dapat mengambil kesimpulan bahwa setelah dilakukan percobaan dalam proses pelatihan dan pengujian sistem yang dilakukan dengan menggunakan software aplikasi Matlab 2011 model jaringan syaraf tiruan yang digunakan adalah 42-1, model 4-3-1, model 4-4-1 dan model 4-5-1, dapat diperoleh hasil yang baik dengan melihat MSE pengujian yang terkecil adalah 4-5-1.

\section{REFERENSI}

[1] Irawan, B. (2007). Fluktuasi Harga, Transmisi Harga dan Marjin Pemasaran Sayuran dan Buah. Analisis Kebijakan Pertanian, Vol. 5, No. 4, pp. 358-373.

[2] Solikhun, Windarto, A.P., Handrizal \& Fauzan, M. (2017). Jaringan Syaraf Tiruan Dalam Memprediksi Sukuk Negara Ritel Berdasarkan Kelompok Profesi Dengan Backpropagation Dalam Mendorong Laju Pertumbuhan Ekonomi. Seminar Ilmiah Nasional Membangun Paradigma Kehidupan Melalui Multidisiplin Ilmu, pp. 14-31.

[3] Solikhun, Safii, M. \& Trisno, A. (2017). Jaringan Saraf Tiruan Untuk Memprediksi Tingkat Pemahaman Siswa Terhadap Matapelajaran Dengan Menggunakan Algoritma Backpropagation. Jurnal Sains Komputer \& Informatika, Vol. 1, No. 1, pp. 24-36.

[4] Matondang, Z.A. (2013). Jaringan Syaraf Tiruan Dengan Algoritma Backpropagation Untuk Penentuan Kelulusan Sidang Skripsi. Pelita Informatika Budi Darma, Vol. IV, No. 1, pp. 84-93.

[5] Sudarsono, A. (2016). Jaringan Syaraf Tiruan Untuk Memprediksi Laju Pertumbuhan Penduduk Menggunakan Metode Backpropagation (Studi Kasus Kota Bengkulu). Media Infotama, Vol. 12, No. 1, pp. 6169.

[6] Windarto, A.P. (2017). Implementasi JST Dalam Menentukan Kelayakan Nasabah Pinjaman KUR Pada Bank Mandiri Mikro Serbelawan Dengan Metode Backpropagation. Jurnal Sains Komputer \& Informatika, Vol. 1, No. 1, pp. 12-23.

[7] Kusmaryanto, S. (2014). Jaringan Saraf Tiruan Backpropagation untuk Pengenalan Wajah Metode Ekstraksi Fitur Berbasis Histogram. Jurnal EECCIS, Vol. 8, No. 2, Desember 2014, pp. 193-198.

[8] Nurmila, N., Sugiharto, A. \& Sarwoko, E.A. (2005). Algoritma Back Propagation Neural Network untuk Pengenalan Karakter Huruf Jawa. Jurnal Masyarakat Informatika, ISSN 2086-4930, Vol. 1, No. 1, pp. 1-10.

[9] Agustin, M. \& Prahasto, T. (2012). Penggunaan Jaringan Syaraf Tiruan Backpropagation untuk Seleksi Penerimaan Mahasiswa Baru pada Jurusan Teknik Komputer di Politeknik Sriwijaya. Jurnal Sistem Informasi Bisnis, Vol. 2, pp. 4-32. 